\title{
Tingkat Penerimaan Masyarakat terhadap Variasi Stik Berbahan Dasar Tepung Daun Katuk
}

\section{The Level of Public Acceptance of Variations of Sticks Made from Katuk Leaf Flour}

\author{
Ernik Rustiana ${ }^{1}$, Siti Suciati ${ }^{2}$ \\ ${ }^{1,2}$ Prodi D3 Kebidanan Universitas Tulungagung \\ 2Email: sitisuciati@unita.ac.id
}

\begin{abstract}
ABSTRAK
Stik Daun Katuk merupakan stik berbahan dasar tepung terigu dengan penambahan tepung daun katuk. Daun kelor mengandung polifenol dan steroid yang dapat meningkatkan kadar prolactin yang berperan dalam memproduksi ASI. Tujuan penelitian ini untuk mengetahui tingkat penerimaan masyarakat terhadap variasi stik berbahan dasar tepung daun katuk. Jenis penelitian ini termasuk observasional dengan pre experimental design. Sampel yang digunakan pada penelitian ini sejumlah 30 panelis yang ditentukan secara accidental sampling yang memenuhi kriteria inklusi dan panelis diminta merasakan dan menilai variasi stik berbahan dasar daun katuk. Penilaian berdasarkan teori organoleptic. Variasi Stik Daun Katuk diuji perbedaan tingkat penerimaan. Analisis statistik tingkat penerimaan menggunakan teknik pengujian Kruskal Wallis dengan nilai alpha 0,05. Berdasarkan hasil pengujian organoleptic dan hedonic dari panelis diketahui ada perbedaan tingkat penerimaan variasi stik berbahan dasar daun katuk baik dari aroma, rasa, tekstur dan warna dengan nilai Asymp. Sig < 0.005. Hasil uji beda tingkat penerimaan terhadap variasi stik daun katuk adalah ada perbedaan tingkat penerimaan pada stik formula 1 , formula 2 , dan formula 3 dengan nilai mean formula 1 sebesar 3.8750 , Formula 2 dengan mean 3.3583 dan formula 3 dengan mean 2.7667. Variasi stik berbahan dasar daun katuk yang paling diterima adalah pada Formula 1. Stik formula1 dengan substitusi penambahan dauk katuk $15 \%$ yang menurut panelis memiliki aroma yang sangat sedap, rasa yang sangat gurih, tekstur dalam kategori empuk serta dari warna menggugah selera.
\end{abstract}

Kata Kunci: Tingkat Penerimaan, Variasi Stik Daun Katuk, Organoleptik

\section{ABSTRACT}

Leaf Katuk sticks are sticks made from wheat flour with the addition of katuk leaf flour. Moringa leaves contain polyphenols and steroids that can increase prolactin levels which play a role in producing breast milk. The purpose of this study was to determine the level of public acceptance of variations of sticks made from katuk leaf flour. This type of research is observational with a pre experimental design. The sample used in this study was 30 panelists who were determined by accidental sampling who met the inclusion criteria and the panelists were asked to feel and assess the variation of sticks made from katuk leaves. Assessment based on organoleptic theory. The variations of the Katuk Leaf Sticks were tested for differences in the level of acceptance. Statistical analysis of the acceptance rate using the Kruskal Wallis testing technique with an alpha value of 0.05. Based on the results of organoleptic and hedonic testing from the panelists, it is known that there are differences in the level of acceptance of variations of sticks made from katuk leaves both in terms of aroma, taste, texture and color with Asymp values. Sig < 0.005. The results of the different acceptance rates for variations of the katuk leaf sticks are that there are differences in the acceptance rates for formula 1, formula 2, and formula 3 sticks with a mean value of formula 1 of 3.8750, Formula 2 with a mean of 3.3583 and formula 3 with a mean of 2.7667. The most accepted variation of sticks made from katuk leaves is in Formula 1. Formulal sticks with the substitution of $15 \%$ katuk leaf addition which according to the panelists have a very delicious aroma, very savory taste, texture in the soft category and the color is appetizing.

Keywords: Acceptance Rate, Katuk Leaf Stick Variation, Organoleptic 


\section{PENDAHULUAN}

Masyarakat di jaman modern ini sebagian besar memiliki kecenderungan memilih makanan tanpa memperhatikan dampak bagi kesehatan. Terutama pada wilayah perkotaan, tinggi kecenderungan masyarakatnya memilih makanan yang praktis dalam memenuhi kebutuhan zat gizinya. Masyarakat sekarang ini sudah banyak yang yang mulai menyadari pentingnya kesehatan. Tingkat kesibukan masyarakat kota yang tinggi membuat kebutuhan makan tidak hanya sebatas pada pemenuhan kebutuhan akan zat gizi bagi tubuh serta cita rasa dan penampilan menarik, akan tetapi makanan harus memiliki manfaat fisiologis tertentu bagi tubuh yang membuat sehat, aman dikonsumsi serta penyajiannya yang praktis (Widyaningsih, 2017).

Berdasarkan hal tersebut, saat ini banyak produsen-produsen makanan dan minuman yang bersaing menciptakan variasi produk-produk makanan yang beragam mulai biskuit, susu, cookies, sereal, minuman berenergi hingga stik. Makanan yang ditawarkan memiliki karakteristik sesuai kebutuhan masyarakat dengan mempertimbangkan segi kesehatan dan kepraktisan. Sehingga produsen makanan, minuman dan juga obatobatan berlomba untuk menciptakan berbagai inovasi makanan dan suplemen menyehatkan, bentuk produk inovasi pun beragam, dari susu, biskuit, cookies, sereal, minuman berenergi hingga stik (Sari, 2016).

Stick merupakan makanan ringan dengan bahan dasar terbuat dari tepung, dibuat dengan cara dicetak dan digoreng. Rasa stik bervariasi tergantung dari bahan dasar tepung yang digunakan. Akan tetapi mayoritas memiliki rasa gurih, teksturnya keras, berbentuk panjang dan berwarna kuning kecoklatan (Oktavianingsih, 2009).

Olahan makanan berbahan dasar daun katuk saat ini masih belum banyak dijumpai, masih minim sekali pemanfaatan tepung daun katuk untuk dijadikan olahan makanan khususnya dalam bentuk snack, roti maupun stik atau camilan. Pada umunya masyarakat memanfaatkan daun katuk sebatas untuk sayur. Stik yang pembuatannya ditambahkan tepung daun katuk dapat digunakan sebagai salah satu alternatif ibu masa nifas meningkatkan produksi ASI nya.

Penelitian ini bertujuan untuk mengetahui tingkat penerimaan masyarakat terhadap variasi Stik 
berbahan dasar tepung daun katuk. Berdasarkan dari data-data di atas maka dilakukan penelitian "Tingkat Penerimaan masyarakat terhadap variasi Stik dengan berbahan dasar Tepung Daun Katuk".

\section{METODE PENELITIAN}

Jenis penelitian ini termasuk observasional dengan pre experimental design desain. Pengambilan sampel menggunakan teknik accidental sampling yaitu pengambilan sampel yang dilakukan dengan kebetulan bertemu yang memenuhi kriteri inklusi. Panelis yang digunakan adalah staf dan mahasiswi Prodi D3 Kebidanan Universitas Tulungagung sebanyak 30 panelis. Waktu penelitian yaitu 1 bulan mulai tanggal 1 - 30 Desember 2020.

Instrumen yang digunakan dalam penelitian berupa angket. Panelis akan diberi stik dan diminta untuk merasakannya. Kemudian panelis menilai bagaimana penerimaan terhadap stik daun katuk yang diberikan. Untuk penilaian yang digunakan adalah penilaian berdasarkan teori organoleptik yang terdiri dari warna, aroma, rasa, dan tektur dari masing-masing formula dan penilain hidonic yang terdiri dari sangat tidak suka, tidak suka, agak suka, suka, sangat suka. Penilaian intrumen menggunakan skala likert 5 tingkat. Uji statistik yang digunakan untuk meihat perbedaan tingkat penerimaan stik formula 1, formula 2 dan formula 3 adalah uji Kruskal-Wallis.

Sebelum melakukan penelitian dilakukan uji reliabilitas. Uji reliabilitas pada penelitian ini menggunakan Uji Cronbach's Alpha. Bila Cronbach's Alpha $\geq 0,6$ maka variable reliable.

\section{HASIL DAN PEMBAHASAN}

\section{Uji reliabilitas}

\begin{tabular}{lccr}
\multicolumn{1}{c}{ Hasil uji } & reabilitas & angket \\
menunjukkan & $\mathrm{r}$ & Alpha & $(0,823)$ \\
mempunyai nilai & lebih & tinggi \\
dibandingkan & 0,6, & sehingga & semua \\
pertanyaan di angket dinyatakan \\
reliabel. Ini berarti dari semua panelis \\
bisa memberikan jawaban dengan \\
konsisten semua penyataan pertama ke \\
penyataan lainya berdasarkan angket \\
yang diberikan.
\end{tabular}

\section{Data Umum Panelis}

1. Karakteristik Responden Berdasarkan Umur

Semua panelis memiliki rentang usia 15-49 tahun. Usia dapat berpengaruh terhadap tingkah laku kesehatan individu. Semakin lanjut usia seseorang, akan mengalami 
perubahan fungsi organ pada tubuh sehingga mengakibatkan gangguan pada hidung dan lidah serta organ tubuh yang lainya (Notoadmodjo, 2007). Secara rutin sel sensor yang bekerja untuk mendeteksi aroma akan mati dan diganti yang baru. Akan tetapi pada lansia proses ini tidak bekerja dengan maksimal yang menyebabkan berkurangnya sel sensor tersebut (Adi, 2012).

Pada penelitian tingkat penerimaan, factor yang memengaruhi terhadap hasil uji adalah umur. Subjek penelitian yang digunakan adalah pria/wanita yang memiliki usia 15-49 tahun karena usia ini lebih peka dan sensitive dibandingkan pada usia tua. Seseorang yang memasuki usia tua mengalami penurunan kepekaan dalam mencicipi makanan baik rasa maupun aroma (Adi, 2012).

2. Karakteristik Responden Berdasarkan Jenis Kelamin

Jenis kelamin dari total 30 panelis hampir semua dari responden yaitu sebanyak 28 orang $(93,3 \%)$ berjenis kelamin perempuan dan 2 panelis $(6,7 \%)$ berjenis kelamin lakilaki.
Jenis kelamin berpengaruh pada penerimaan makanan dan nafsu makan. Pada pola penerimaan terhadap makanan, perempuan menyukai jumlah makanan lebih banyak dibandingkan laki-laki (Saphira Shafa Nada, 2020). Sensitivitas terhadap rasa maupun aroma lebih tinggi dimiliki oleh wanita. Wanita juga lebih peka dibandingkan laki-laki dalam menanggapi rangsangan rasa manis (Wijoyo S, 2011).

3. Karakteristik Responden Berdasarkan Status Kesehatan Keseluruhan panelis panelis) memiliki status kesehatan yang baik. Kesehatan merupakan hal yang penting bagi seseorang dalam mengkonsumsi makanan. Orang dengan kondisi kesehatan yang kurang baik bisa mengalami suatu perubahan didalam mempersepsikan rasa (Wijoyo S, 2011). Panelis dengan kondisi yang tidak sehat akan mempengaruhi pada tingkat penerimaan variasi stik berbahan dasar daun katuk. Untuk itu orang yang dalam kondisi tidak sehat tidak diikutkan dalam penelitian dikarenakan berpengaruh pada hasil uji penerimaan stik daun katuk. 
4. Karakteristik

Responden

Berdasarkan Status Kebiasaan merokok

$$
\text { Keseluruhan panelis }
$$
panelis) tidak memiliki kebiasaan merokok. Faktor faktor yang mempengaruhi persepsi terhadap rasa antara lain kebiasaan merokok, pertambahan usia (Akal et al, 2003). Rokok mengandung setidaknya 7000 zat kimia beracun dan bersifat karsinogenik. Zat-zat tersebut menyebabkan berbagai efek negatif bagi rongga mulut dan sistem dalam tubuh lainnya. Efek yang sering tidak disadari oleh perokok adalah berkurangnya kemampuan mengecap (Tjahajawati Sri dkk, 2019). Dalam penelitian penerimaan stik daun katuk panelis yang digunakan adalah yang tidak memiliki kebiasaan merokok agar tidak mempengaruhi daya terima terutama yang berhubungan dengan aspek rasa.

\section{Hasil Uji Organoleptik Stik dengan \\ Penambahan Tepung Daun Katuk}

Panelis menilai aroma stik dengan penambahan tepung daun katuk pada formula 1 dengan nilai 4.03, yang berarti aroma dari stik sangat sedap. Untuk rasa panelis memberikan penilaian hampir sama dengan aroma yaitu 4.10 yang berarti stik memiliki rasa yang sangat gurih. Pada tekstur stik dinilai 3.67, maka tekstur dari stik dalam kategori empuk. Sedangkan dari warna panelis memberikan penilaian 3.70 yang artinya mayoritas panelis menyukai warna stik pada formula 1 dalam kategori menggugah selera.

Penilaian dari 30 panelis untuk stik daun katuk formula 1 mendapatkan nilai mean sebesar 3.8750 yang berarti panelis suka terhadap stik daun katuk formula 1 dengan aromanya yang sedap, rasanya gurih, tekstur empuk dan warna yang menggugah selera.

Daun katuk merupkan jenis sayuran yang memiliki zat gizi dan zat metabolic sekunder yang tinggi, sehingga katuk dapat digunakan untuk sayur dan sebagai obat herbal (Urip Santoso, 2016). Manfaat daun katuk salah satunya adalah mampu memperlancar produksi ASI (Santoso Hieronimus Budi, 2008). Senyawa yang ada dalam daun katuk adalah asam seskuiterna (Santoso Hieronimus Budi, 2008). Kandungan sterol yang ada dalam daun katuk berfungsi untuk meningkatkan metabolisme glukosa untuk mensintesa laktosa, sehingga jumlah ASI meningkat. Disamping itu 
daun katuk juga mengandung polifenol dan steroid yang bertugas dalam refleksi hormone prolaktin atau alveoli dalam memproduksi ASI maupun merangsang hormon oksitosin untuk mempercepat aliran dan keluarnya ASI (Ramayulis Rita, 2015).

Untuk stik formula 2 panelis menilai aroma stik 3.60, yang berarti masih dalam kategori sedap. Sedangkan dari rasa panelis memberikan penilaian 3.43 dimana rasa stik tersebut masih gurih walaupun ditambahkan dengan tepung daun katuk lebih banyak dibandingkan dengan formula 1. Panelis juga memberikan penilaian yang sama dengan tekstur stik yaitu 3.43, berarti tekstur stik masih empuk. Dari warna didapatkan nilai 2.97, ini menunjukkan dari warna stik agak menggugah selera.

Penilaian dari 30 panelis untuk stik daun katuk formula 2 mendapatkan nilai mean sebesar 3.3583 yang berarti panelis suka terhadap stik daun katuk formula 2 dengan aromanya yang sedap, rasanya gurih, tekstur empuk dan warna yang agak menggugah selera.

Hasil penilaian ini perlu untuk dilakukan evaluasi apakah stik perlu ditambahkan pewarna makanan sehingga akan memiliki warna yang lebih menggugah selera sehingga ibu menyusui akan lebih tertarik untuk mengkonsumsi stik dengan penambahan tepung daun katuk mengingat sasaran pemasaran stik ini adalah ibu menyusui.

Ibu menyusui pada penelitian Waruwu (2017) menyatakan bahwa untuk meningkatkan selera makan seseorang untuk mau mengkonsumsi makanan dapat dilakukan dengan membuat modifikasi resep yang menarik. Modifikasi resep merupakan suatu tindakan dalam membuat resep baru dengan cara merubah resep dasar yang ada baik dengan mengurangi bumbu, merubah bentuk dan cara pengolahan masakan dengan tujuan untuk meningkatkan nilai gizi dari sebuah makanan (Purnamasari Nove Andari, 2019).

Untuk itu perlu dilakukan modifikasi pengolahan daun katuk salah satunya adalah dalam bentuk stik ini.

Pada aroma stik formula 3 panelis memberikan nilai 3.00 , berarti mereka kurang meyukai kareda aroma dari stik agak tidak sedap. Begitu juga dengan rasanya panelis juga kurangmenyukai karena kurang gurih dibandingkan dengan formula 1 dan 2 . Dari tekstur juga memiliki range penilaian yang sama dimana panelis menilai stik agak keras. Untuk warna 
panelis memberikan penilaian agak menggugah selera.

Penilaian dari 30 panelis untuk stik daun katuk formula 3 mendapatkan nilai mean sebesar 2.7667 yang berarti panelis agak suka terhadap stik daun katuk formula 3 dengan aromanya yang agak tidak sedap, rasanya kurang gurih, tekstur agak keras dan warna yang agak menggugah selera. Stik formula 3 kurang disukai karena aroma tepung daun katuk lebih menyengat seperti aroma obat hebal, disamping itu stik juga lebih keras serta agak terasa seperti ada pasirnya sehingga terasa kasar dilidah.

Pada stik formula 3 perlu di kaji ulang sehingga hasilnya tidak begitu jauh berbeda dengan formula 1 dan 3 . Penambahan perasa makanan ataupun bumbu mungkin akan memberikan rasa maupun aroma yang lebih sedap sehingga bisa diterima oleh panelis.

Penerimaan terhadap variasi stik berbahan dasar tepung daun katuk ada perbedaan antara formula 1, 2 dan 3 dengan nilai mean pada stik formula 1 , formula 2, dan formula 3 dengan nilai mean formula 1 sebesar 3.8750 , Formula 2 dengan mean 3.3583 dan formula 3 dengan mean 2.7667 .
Daya terima konsumen yaitu kesediaan seseorang untuk mengkonsumsi suatu produk secara teratur. Daun katuk memiliki aroma yang khas seperti ramuan herbal. Semakin tinggi banyak prosentase penambahan daun katuk dalam suatu makanan maka aroma, rasa dan teksturnya akan berbeda.

\section{SIMPULAN DAN SARAN}

Variasi stik berbahan dasar daun katuk yang paling diterima adalah pada Formula 1. Stik formula1 dengan substitusi penambahan dauk katuk 15\% yang menurut panelis memiliki aroma yang sangat sedap, rasa yang sangat gurih, tekstur dalam kategori empuk serta dari warna menggugah selera.

Adapun saran dari penelitian ini yaitu: Melakukan uji lanjutan untuk menguji perbedaan Mean antara formula 1 , formula 2 dan formula 3 , dan melakukan uji laboratorium untuk mengetahui kandungan gizi pada formula 1 , formula 2 dan formula 3 . 


\section{DAFTAR PUSTAKA}

Adi. 2012. Mengapa Lansia jadi Kurang Peka pada Aroma Rasa dan Makanan. Jakarta: Detik.com.

Brief.

http://www.who.int/nutrition/pu blications/globaltargets2025_pol icybrief_breastfeeding/en/.

Notoatmodjo. 2007. Metodologi penelitian kesehatan. Edisi revisi. Jakarta: Rineka Cipta.

Oktavianingsih Y. 2009. Pengaruh Fortifikasi Tepung Rumput Laut Eucheuma cottonii pada Stick Ikan Kuniran (Upeneus sp.)

Purnamasari Novi Andarani. 2019. Pengaruh Modifikasi Makanan Pokok Terhadap Daya Terima Balita Di Taman Penitipan Anak (Tpa) Cinta Kota Palangka Raya. Skripsi. Politeknik Kesehatan Kemenkes Palangkaraya.

Ramayulis Rita. 2015. Green Smootie 100 Resep 20 Khasiat. Gramedia Pustaka Utama: Jakarta.

Sakti Eka S. 2018. Infodatin Pusat data dan Informasi Kementerian Kesehatan RI. Jakarta: Kemenkes RI.

Santoso Urip. 2016. Katuk, Tumbuhan Multi Khasiat. Tersedia di https://www.researchgate.net/pu blication/303994522
Santoso Hieronimus Budi. 2008. Ragam \& Kasiat Tanaman Obat Sehat Alami dari Halaman Asri. Agromedia Pustaka: Jakarta.

Saphira Shafa Nada. 2020. Hubungan Perilaku Picky eater dengan Status Gizi Anak USIA 4-6 Tahun. Skripsi. Trisakti.

Sari, S.M. 2016. Perbandingan Tepung Sorgum, Tepung Sukun, dengan Kacang Tanah dan Jenis Gula terhadap Karakteristik Snack Bar. Program Studi Teknologi Pangan Fakultas Teknik Universitas Pasundan. Bandung.

Suprayogi, A., 2012. Peran Ahli Fisiologi Hewan Dalam Mengantisipasi Dampak Pemanasan Global Dan Upaya Perbaikan Kesehatan Dan Produksi Ternak. Scientific Repository IPB, 2012.

Tjahajawati Sari dkk. 2019. Perbedaan Sekresi Saliva, Ambang Kecap, Tekanan Darah, Kadar Glukosa Darah Pada Wanita Perokok Dan Non-Perokok.

Wijoyo S. 2011. pengaruh usia dan jenis kelamin terhadap ambang batas (absolute threshold) umami. Tersedia di http://repository.unika.ac.id/818 7/1/08.70.0141\%20Stephanie\%2 0Wijoyo_2\%20COVER.pdf

Widyaningsih, T.D; Wijayanti, $\mathrm{N}$ dan Nugrahini, N.I.P. 2017. Pangan Fingsional. Malang Universitas Brawijaya Media 